\title{
INTRAMUSCULAR INJECTION OF PROCAINE PENICILLIN COMBINED WITH ORAL ADMINISTRATION OF CHLORAMPHENICOL IN THE TREATMENT OF GONORRHOEA*
}

\author{
BY \\ H. C. GJESSING AND K. ÖDEGAARD \\ From the Bureau of Public Health, Department of Venereal Diseases, and the National Institute of Public Health, \\ Department of Bacteriology, Oslo, Norway
}

In the last few years we have witnessed an increase in the numbers of gonococcal strains which are relatively resistant to penicillin and a subsequent rise in treatment failures. It was therefore considered necessary to find a substitute for, or a modification of, the routine treatment with benzyl procaine penicillin.

In a previous paper (Gjessing and Ödegaard, 1965), the results of intramuscular injection of procaine penicillin combined with the oral administration of ampicillin have been described, and the pharmacological, psychological, and epidemiological reasons why it was considered advantageous to continue the injection of procaine penicillin combined with oral ampicillin are briefly discussed.

The present paper deals with the injection of procaine penicillin combined with oral chloramphenicol. Since 1959 when we started the routine examination of the sensitivity of gonococci to several antibiotics, not a single strain with reduced sensitivity to chloramphenicol was observed in more than 2,000 cases. In several cases of relapse after the intramuscular injection of benzyl procaine penicillin, oral chloramphenicol was given without further failure. We have observed no complications due to this drug, although serious side-effects, especially aplastic anaemia, have been described by other workers. Shaw and McLean (1957) reported lethal cases following the administration of only 3.5 and $8 \mathrm{~g}$. chloramphenicol. However, it seems that complications are usually due to large doses and/or prolonged treatment. We have not used chloramphenicol intramuscularly because this method is often accompanied by severe local pain and faintness (Willcox, 1963).

As far as is known no serious harm has been observed after the oral administration of chloramphenicol in very small doses, e.g. 1 g., and we therefore considered it worth while to try a schedule consisting of one intramuscular injection of procaine penicillin 600,000 units combined with oral chloramphenicol in doses of 0.5 or $0.75 \mathrm{~g}$.

\footnotetext{
* Received for publication April 26, 1965.
}

Material and Methods

The subjects of the trial were 500 consecutive male patients, all of whom received one intramuscular injection of 600,000 units procaine penicillin. At the same time as the injection, the first 250 patients were given a single dose of $0.5 \mathrm{~g}$. chloramphenicol ( 2 tablets of $0.25 \mathrm{~g}$.) (Series I), and the following 250 patients a single oral dose of $0.75 \mathrm{~g}$. chloramphenicol ( 3 tablets of $0.25 \mathrm{~g}$.) (Series II). The patients were told that the tablets were only a reinforcement of the injection. This scheme of treatment was used from February to December, 1964.

The methods of diagnosis, sensitivity tests, follow-up, and distinction between relapse and re-infection were the same as described in previous papers (Gjessing, 1959; Gjessing and Ödegaard, 1962a, b). The plate dilution method was employed to determine the sensitivity of the gonococci to penicillin. The paper disk method was used to determine sensitivity to streptomycin, chloramphenicol, tetracycline, erythromycin, and sulphonamide. The results of this latter method are not discussed in the present paper.

To ascertain that the patients in the present series were cured, especially those infected with gonococci less sensitive to penicillin, we used in many instances cultural tests as well as direct microscopical examination during the follow-up period.

\section{Results}

The results of treatment are shown in Table I, opposite.

Series I included five treatment failures compared with ten in Series II, despite the fact that the dose of chloramphenicol in Series II was higher. This may be explained by the occurrence of more strains with decreased sensitivity to penicillin in Series II, which also included three patients with gonococci of which the minimum inhibitory concentration of penicillin was 2 units $/ \mathrm{ml}$. Strains with such a high resistance have not been observed before in Oslo.

In the 500 patients there were fifteen treatment failures ( 3 per cent.), and thirteen of them occurred among the 256 patients infected with gonococci less sensitive to penicillin. The failure rate in this group is consequently $5 \cdot 1$ per cent.

Only two cases of relapse were registered in the sensitive group. However, because it is often 107 
TABLE I

RESULTS IN SERIES I AND II

\begin{tabular}{|c|c|c|c|c|c|c|c|c|c|c|c|c|c|c|c|c|}
\hline \multirow{4}{*}{\multicolumn{2}{|c|}{$\begin{array}{c}\text { Minimum } \\
\text { Inhibitory } \\
\text { Concentration } \\
\text { of Penicillin } \\
\text { (units/ml.) }\end{array}$}} & \multicolumn{5}{|c|}{$\begin{array}{c}\text { Series I } \\
\text { Procaine penicillin } 600,000 \text { units } \\
+ \text { chloramphenicol 0.5 } \mathrm{g} . \\
\text { (Feb. to July, 1964) }\end{array}$} & \multicolumn{5}{|c|}{$\begin{array}{l}\text { Series II } \\
\text { Procaine penicillin } 600,000 \text { units } \\
+ \text { chloramphenicol } 0 \cdot 75 \mathrm{~g} . \\
\text { (July to Dec., 1964) }\end{array}$} & \multicolumn{5}{|c|}{$\begin{array}{l}\text { Total } \\
\text { to Dec., 1964) }\end{array}$} \\
\hline & & \multirow{3}{*}{$\begin{array}{l}\text { No. of } \\
\text { Patients }\end{array}$} & \multicolumn{3}{|c|}{ Followed up } & \multirow{3}{*}{$\begin{array}{l}\text { Not } \\
\text { Fol- } \\
\text { lowed } \\
\text { up }\end{array}$} & \multirow{3}{*}{$\begin{array}{l}\text { No. of } \\
\text { Patients }\end{array}$} & \multicolumn{3}{|c|}{ Followed up } & \multirow{3}{*}{$\begin{array}{c}\text { Not } \\
\text { Fol- } \\
\text { lowed } \\
\text { up }\end{array}$} & \multirow{3}{*}{$\begin{array}{l}\text { No. of } \\
\text { Patients }\end{array}$} & \multicolumn{3}{|c|}{ Followed up } & \multirow{3}{*}{$\begin{array}{l}\text { Not } \\
\text { Fol- } \\
\text { lowed } \\
\text { up }\end{array}$} \\
\hline & & & \multicolumn{2}{|c|}{ Gc. Positive } & \multirow{2}{*}{$\begin{array}{l}\text { Gc. } \\
\text { Neg- } \\
\text { ative }\end{array}$} & & & \multicolumn{2}{|c|}{ Gc. Positive } & \multirow{2}{*}{$\begin{array}{l}\text { Gc. } \\
\text { Neg- } \\
\text { ative }\end{array}$} & & & \multicolumn{2}{|c|}{ Gc. Positive } & \multirow{2}{*}{$\begin{array}{l}\text { Gc. } \\
\text { Neg- } \\
\text { ative }\end{array}$} & \\
\hline & & & Relapse & $\begin{array}{c}\mathrm{Re}- \\
\text { infection }\end{array}$ & & & & Relapse & $\begin{array}{c}\mathrm{Re}- \\
\text { infection }\end{array}$ & & & & Relapse & $\begin{array}{c}\mathrm{Re}- \\
\text { infection }\end{array}$ & & \\
\hline $\begin{array}{l}\text { Less } \\
\text { Sensi- } \\
\text { tive }\end{array}$ & $\begin{array}{l}2 \\
1 \\
0 \cdot 50 \\
0 \cdot 25 \\
0 \cdot 125\end{array}$ & $\left.\begin{array}{r}0 \\
6 \\
52 \\
54 \\
13\end{array}\right\} 125$ & 4 & $\begin{array}{l}1 \\
2\end{array}$ & $\begin{array}{r}5 \\
34 \\
31 \\
8\end{array}$ & $\begin{array}{r}16 \\
19 \\
5\end{array}$ & $\left.\begin{array}{r}3 \\
18 \\
46 \\
59 \\
5\end{array}\right\} 131$ & $\begin{array}{l}3 \\
3 \\
1 \\
2\end{array}$ & $\begin{array}{l}1 \\
1\end{array}$ & $\begin{array}{r}11 \\
28 \\
38 \\
2\end{array}$ & $\begin{array}{r}4 \\
16 \\
18 \\
3\end{array}$ & $\left.\begin{array}{r}3 \\
24 \\
98 \\
113 \\
18\end{array}\right\} 256$ & $\begin{array}{l}3 \\
3 \\
1 \\
6\end{array}$ & $\begin{array}{l}1 \\
3 \\
1\end{array}$ & $\begin{array}{l}16 \\
62 \\
69 \\
10\end{array}$ & $\begin{array}{r}4 \\
32 \\
37 \\
8\end{array}$ \\
\hline $\begin{array}{l}\text { Sensi- } \\
\text { tive }\end{array}$ & $\begin{array}{c}0.06 \\
0.03 \\
\leqq 0.015\end{array}$ & $\left.\begin{array}{l}12 \\
71 \\
42\end{array}\right\} 125$ & 1 & $\begin{array}{l}1 \\
2 \\
1\end{array}$ & $\begin{array}{r}9 \\
43 \\
25\end{array}$ & $\begin{array}{r}2 \\
25 \\
16\end{array}$ & $\left.\begin{array}{r}9 \\
71 \\
39\end{array}\right\} 119$ & 1 & $\begin{array}{l}4 \\
1\end{array}$ & $\begin{array}{r}7 \\
47 \\
26 \\
\end{array}$ & $\begin{array}{r}2 \\
20 \\
11\end{array}$ & $\left.\begin{array}{r}21 \\
142 \\
81\end{array}\right\} 244$ & $\begin{array}{l}1 \\
1\end{array}$ & $\begin{array}{l}1 \\
6 \\
2 \\
\end{array}$ & $\begin{array}{l}16 \\
90 \\
51 \\
\end{array}$ & $\begin{array}{r}4 \\
45 \\
27 \\
\end{array}$ \\
\hline$\overline{\text { Total }}$ & $\cdots$ & 250 & $(2 \%)$ & 7 & 155 & 83 & 250 & $\begin{array}{c}10 \\
(4 \%)\end{array}$ & 7 & 159 & 74 & 500 & $\begin{array}{c}15 \\
(3 \%)\end{array}$ & 14 & 314 & 157 \\
\hline
\end{tabular}

difficult to distinguish relapse from re-infection, one may suspect that a few "failures" were, in fact, re-infections. The patients' statements regarding re-exposure to risk of infection are notoriously unreliable, but they cannot be disregarded entirely because unknown factors, such as malabsorption or abuse of alcohol, can have played a part.

\section{Treatment of First Relapse}

Eleven patients received oxytetracycline $0.25 \mathrm{~g} . \times 32$, one tablet four times a day 4-hrly. Nine were cured and two relapsed for a second time. In these two cases, the sensitivity tests did not indicate reduced sensitivity to tetracycline.

Three patients were treated with ampicillin $0 \cdot 25 \mathrm{~g} . \times 48$, two tablets four times a day 4-hrly and all were cured.

One patient was successfully treated with chloramphenicol $0 \cdot 25 \mathrm{~g} . \times 36$, two tablets four times a day 4-hrly for three days, followed by one tablet four times a day for 3 days.

\section{Treatment of Second Relapse}

One patient was infected with gonococci with a minimum inhibitory penicillin concentration of 2 units $/ \mathrm{ml}$.
The first relapse was treated unsuccessfully with oxytetracycline. The second relapse was cured by ampicillin in the above-mentioned dosage.

Another patient in whom the gonococci had a minimum inhibitory concentration of 0.25 units $/ \mathrm{ml}$., was also treated for the first relapse with oxytetracycline, and the second relapse was successfully treated with ampicillin in the above mentioned dosage.

\section{Comparison of Different Treatment Schedules}

The efficacy of different treatment schedules cannot be compared without consideration of the proportion of sensitive and less sensitive strains of gonococci in each series of patients. The results in each group of strains must be compared separately. The main interest lies in infections caused by gonococci with decreased sensitivity to penicillin. In Table II, the results of the schedule described above are compared with those in corresponding groups in two previous schedules (Gjessing and Ödegaard, 1964, 1965). In all three groups, the methods apart from the actual treatment were the same, and all examinations were undertaken or supervised by the same persons.

TABLE II

TREATMENT FAILURES IN INFECTIONS CAUSED BY GONOCOCCI WITH REDUCED SENSITIVITY TO PENICILLIN G (Minimum inhibitory concentrations $0 \cdot 125-2$ units $/ \mathrm{ml}$.)

\begin{tabular}{|c|c|c|c|}
\hline No. of Patients & $\begin{array}{c}\text { Schedule I } \\
\text { June, 1961, to Nov., } 1962 \\
\text { Intramuscular Procaine Penicillin } \\
600,000 \text { units }\end{array}$ & $\begin{array}{c}\text { Sechdule II } \\
\text { Dec., 1962, to Feb., 1964 } \\
\text { Intramuscular Procaine Penicillin } \\
600,000 \text { units + oral ampicillin } 1 \mathrm{~g} .\end{array}$ & Schedule III* \\
\hline 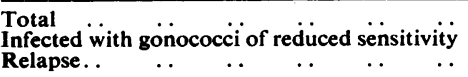 & $\begin{array}{l}500 \\
169 \\
50(29 \cdot 6 \text { per cent. })\end{array}$ & $\begin{array}{l}500 \\
207 \\
15 \text { ( } 7 \text { per cent. })\end{array}$ & $\begin{array}{l}500 \\
256 \\
13(5 \cdot 1 \text { per cent. })\end{array}$ \\
\hline
\end{tabular}

* Made up of Series I and II as detailed in Table I. 
Schedule I (one intramuscular injection of 600,000 units procaine penicillin) had a failure rate of 29.6 per cent, when the infection was caused by gonococci with reduced sensitivity to penicillin. When an oral dose of $1 \mathrm{~g}$. ampicillin was added (Schedule II), the failure rate fell to 7 per cent., and when an oral dose of 0.5 to $0.75 \mathrm{~g}$. chloramphenicol was added (Schedule III) the failure rate fell to $5 \cdot 1$ per cent.

\section{Summary}

Series I. -250 male patients were given one intramuscular injection of 600,000 units procaine penicillin and an oral dose of $0.5 \mathrm{~g}$. chloramphenicol which was swallowed under supervision.

Series II. - 250 male patients were given the same injection of procaine penicillin, but the dose of chloramphenicol was increased to $0.75 \mathrm{~g}$.

There were five treatment failures in Series I and ten in Series II.

There were far more strains of gonococci with reduced sensitivity to penicillin in Series II than in Series I.

In 256 patients in the two series taken together who were infected with gonococci less sensitive to penicillin (minimum inhibitory concentration $0 \cdot 125$ -2 units $/ \mathrm{ml}$.) there were thirteen relapses; a failure rate of $5 \cdot 1$ per cent. compared with 3 per cent. in all cases, and in the 244 patients infected with gonococci sensitive to penicillin (minimum inhibitory concentration $\bar{₹} 0.06$ units $/ \mathrm{ml}$.) there were only two treatment failures.

Eleven cases of relapse were treated with oxytetracycline, of which nine were cured and two relapsed for a second time. Three patients with a first relapse were all cured by ampicillin, and one with a first relapse by chloramphenicol. The two patients who had a second relapse were cured by ampicillin.

\section{REFERENCES}

Gjessing, H. C. (1959). Brit. J. vener. Dis., 35, 256. and Ödegaard, K. (1962a). Ibid., 38, 26.

305 . (1962b). Acta derm.-venereol. (Stockh.), 42, 305. (1964). Ibid., 44, 132.

- (1965). Brit. J. vener. Dis., 41, 48.

Shaw, R. G., and McLean, J. A. (1957). Med. J. Aust., 1, 352 (Cited in Brit. med. J., 1961, 1, 1019).

Willcox, R. R. (1963). Brit. J. vener. Dis., 39, 160.

L'injection intramusculaire de procaine-pénicilline combinée au chloramphenicol par voie buccale dans le traitement de la blennorragie

\section{RÉSUMÉ}

Première série. -250 hommes ont reçu une injection intramusculaire de $600,000 \mathrm{u}$. de procaine-pénicilline et une dose orale de $0,5 \mathrm{~g}$. de chloramphenicol.

Deuxième série.-250 hommes ont reçu la même injection de procaine-pénicilline, mais la dose de chloramphenicol avait été augumentée et était de $0,75 \mathrm{~g}$.

Il y a eu cinq échecs dans le traitement de la première série et dix dans la deuxième. Il y avait beaucoup plus de souches de gonocoques montrant une sensibilité réduite à la pénicilline dans la deuxième série que dans la première.

Chez 256 malades des deux séries prises ensemble qui avaient été infectés par des gonocoques moins sensibles à la pénicilline (concentration inhibitrice minimum 0,125-2 unités $/ \mathrm{ml}$.) il y a eu treize rechutes; un taux d'échecs de $5,1 \%$ comparé à $3 \%$ dans tous les cas, et chez les 244 malades contaminés par des gonocoques sensibles à la pénicilline (concentration inhibitrice minimum $\bar{\gtrless} 0,06$ unités $/ \mathrm{ml}$.) il y a eu seulement deux échecs dans le traitement.

Onze rechutes ont été traitées avec de l'oxytétracycline, neuf d'entre elles ont été guéries et deux ont eu une seconde rechute. Après une première rechute trois malades ont été guéris par de l'ampicilline et un malade par le chloramphenicol. Les deux malades qui avaient eu une seconde rechute ont été guéris par l'ampicilline. 